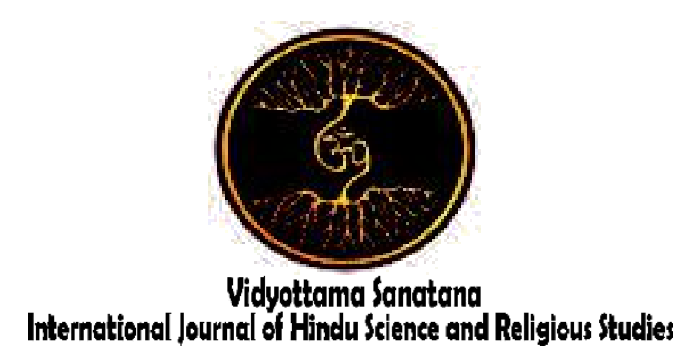

Vol. 3 No. 2 October 2019

\title{
THE RELATIONSHIP BETWEEN RELIGIOUS TRIBES IN TENGGER (HINDU, ISLAM AND BUDHA)
}

\author{
By: \\ M. Thoriqul Huda, Irma Khasanah \\ Institut Pesantren KH Abdul Chalim Mojokerto, UIN Sunan Ampel Surabaya \\ E-mail : huda90.ikhac@gmail.com, Irmakhasanahlmj16@gmail.com
}

\begin{tabular}{|l|l|l|} 
Received: August 09, 2019 & Accepted: September 19, 2019 & Published: October 31, 2019 \\
\hline
\end{tabular}

\begin{abstract}
Indonesia including State that has a diversity of tribes, ethnicities, races, languages, religions, and cultures. However, with this diversity is able to cause conflict both internal and external. As with many cases going on in Indonesia. Religion is itself a foothold, beliefs, and guidelines for living, even too often scapegoats the incidence of conflict in society. However, the other by the tenggerese is located in Lumajang, Malang, Pasuruan Regency Probolinggo Regency here and there are three religions living side by side in one village i.e. Islam, Hinduism, and Buddhism. In the middle of kemajemukan different communities understand and belief turns out to be able to have an attitude of tolerance and mutual respect between each other. Keberanekaragaman religion is not an issue of community agrosari to interact in everyday activities. Regarding religious tolerance have lately become a very good sticking issues among academics as well as the community. Local wisdom and culture be the solution to resolve the issue. Local wisdom on the tenggerese community of Javanese cultural values, as well as the cultural heritage of the Majapahit Empire which is still developing with mutual interlocking appreciate attitude, tolerance, and respect in the spirit of the ancestors and there is no tribal differences are striking in addition to differences of religious belief. The togetherness that is manifested in the form of the ritual customs such as the ceremony of the unan-unan, Bari'an (celebrate). Each religion has its own demands tolerance on the tenggerese is already deeply ingrained, tenggerese community also upholds the values of equality and democracy in the life of society as well as more respectful of religious leaders and shaman (spiritual teacher) than leader administrativ. Since all are brothers, all families, remain peaceful and trustful that became the pillars as well as ancestral heritage.
\end{abstract}

Keywords: Relationship Between Religion, Rituals, Tengger 


\section{INTRODUCTION}

Indonesia strongly holds fast to the legacy of ancestral messages i.e. motto "Bhineka Tunggal Ika" which means that even though there is a difference, however, remains a jua, Concord was a most important pillars as the Foundation of the society in maintaining the integrity of a nation unity. The Foundation of the unity both of the strong, the tribe, religion, language, race and religion, then this will be easy Indonesia nation pitted the sheep as well as threatened will experience Division. Religious diversity is potentially extremely strong against the identity of each religion that will potentially cause a conflict. Own compactness is understood as the condition of a life that is created in a sunny, peaceful, mutually appreciative between fellow, mutual respect, and mutual. Harmony between religious created in order not to conflict, as well as hostility from both the intern and the religious believers to another. Religious unity itself can be interpreted with the social conditions in which all religions can live side by side in one place without prejudice to the obligations and rights of their respective religions. Concord is a requirement that cannot be postponed any longer.

Achievement of a harmonious atmosphere in the life of the community. This is manifest in a sense of mutual respect between religions. Freedom in embracing religion and worship in accordance with the beliefs of each and not impose beliefs against other religions by mutual trust between both the internal as well as external fellow religions by the Government for the sake of the realization of a harmonious society and is responsible for maintaining the religion and the nation. ${ }^{1}$ As already described in the Qur'an that humanity was created to know each other,

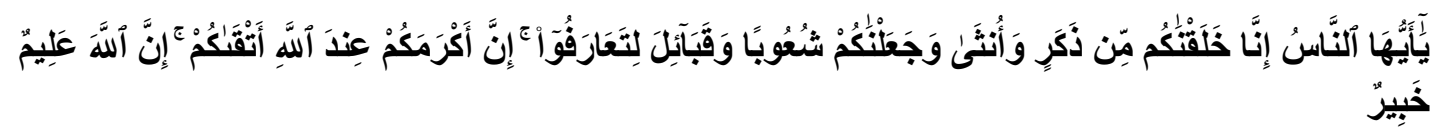

"People, we created you from a male and a female, and made you bersuku-suku that you berbangsa-bangsa and kenal-mengenal each other. Indeed, the most honourable among you thee a God is the most Religious among you. Surely, Allah is all-knowing and most Recognise " 2

The text shows that there is harmony in life, unity becomes the handle of each religious group so that it is easier to build social and religious interactions. If a religious group has been in touch with the other then the interaction easier in developing working relationships, mutual and mutually particularly in the preservation of the traditions of the societies to build social relationships and a country. ${ }^{3}$ Departing from description above can be an interesting thing to be reviewed and examined related religious

${ }^{1}$ H.R. Djatiwijono, Dinamika Kerukunan Hidup Beragama Di Daerah (Jakarta: Maret, 1983), 5

2 Al-Quran, Surat Al Hujurat Ayat 13 harmony in the Tenggerese (Tribe who live and reside under the slopes of Mount Semeru, the species is present in four counties including: Regency Pasuruan, Probolinggo, Regency Lumajang and Malang). Tenggerese community strongly uphold notability and have great respect for customary and traditional birth attendants (leader of the Faithful) from a Government Chief.

Realization of maintaining religious harmony in the tenggerese to do preservation of existing local wisdom tradition in the area

${ }^{3}$ Said Aqil Al- Munawar, Fiqh Hubungan Antar Agama, ( Jakarta: Ciputat Press, 2005), 22 
according to the tenggerese shaman there local wisdom of this ancestral heritage during the majapahit Empire that still held until now. Like the ceremony of Unan-Unan, KaroKaro, funerals, wedding ceremony, Kasada. On discussion of the tenggerese discusses related harmony which is often done by Hindus and Muslims, namely the ceremony unan-unan and bari'an. Unan-unan ceremonies in Hindu calendar implemented sewindu once does not mean 8 years but 5 years in Hindu calendar. ${ }^{4}$ So is the ceremony Bari'an done tenggerese Muslims once a year as a form of speech of gratitude to God the result the abundant earth. ${ }^{5}$ The traditions that often they do together as customary as well as existing Norms on the tenggerese to keep each other keeping harmony and social with people of different beliefs though tenggerese. ${ }^{6}$

\section{The Relationship Between Religions}

Indonesia is the anniversary according to the diverse richness of every different regions both in terms of tribe, race, language, religion and culture. This diversity as a nation a pioneer in creating religious harmony for easy partnership,${ }^{7}$ on the other hand, religion has two impacts i.e. Centripetal (as he is) and centrifugal (Solvers). ${ }^{8}$ Two of these impacts that trigger theory posited on religious relations. Maintaining religious unity need not be marked with the emergence of different religions that is such that already looks every religion has a different complexion from both the system kelolah kelembagaannya, beliefs, laws that set.

\footnotetext{
${ }^{4}$ Robert W. Hefner, Hindu Javanes And Tradition Islam (Princeton: Princeton University Perss, 1985), 17

${ }^{5}$ Mohammad Ali Hisyam, Harmonisasi Lintas Agama Masyarakat Tengger, Vol 10, N0 01, September 2015

${ }^{6}$ Joko Tri Haryonto, Kearifan Lokal Pendukung Kerukunan Beragama Pada Komunitas Tengger Malang Jatim, Vol 21, No 2 Tahun 2004.

${ }^{7}$ Mursid Ali, Plularitas Sosial Dan Hubungan Antar Agama Bingkai Kulturall Dan Theologi, Kerukunan Hidup Umat
}

Mukti Ali expressed his thoughts about "agree in at segrement". That assumes that this is through the concept of can maintain religious harmony. By the way have to believe that religion is the truest dipeluknya, and other religions were invited to trust religion that dipeluknya is also the most correct. The concept of mutual trust between this fellow can take country Indonesia into one unified whole is not easily torn asunder. ${ }^{9}$

The harmony between the first believers were located on the attitude of tolerance to be built for addressing the existing harmony. For this country of tolerance is extremely necessary in maintaining religious frame views of bermacam-macamnya religion that developed in Indonesia is not only a recognized Islamic State in Indonesia, but there are also five other religions such as Hinduism, Buddhism, Christian, Catholic, and Confucianism. ${ }^{10} \mathrm{We}$ ought to be proud of your own tolerance but on the other hand, there is the saturation of the religions because indirectly tolerance alone can bring up the existence of the attitude of the Apologists (an attitude which is used for the defence of the faith). ${ }^{11}$ Religions say that religion in the most yakinilah have a strong attitude of tolerance of other religions on the teachings, from here will be new tensions arise which are Textual (written), and contextual (Anthropology, sociology, and History).

The theologian and politician claimed the blessing of the existence of the pancasila

\footnotetext{
Beragama, (Jakarta: Badan Peneliti Pengembangan Agama Depag RI, 1999), 11

${ }^{8}$ M. Mundar Soelaeman, Ilmu Sosial Dasar Teori Dan

Konsep Ilmu Sosial, (Bandung: ERSCO,1987), 229

${ }^{9}$ Mukti Ali, Ilmu Perbandingan Agama, Dialog, Dakwah

Dan Misi, (Jakarta: Inis, 1997), 227-229

${ }^{10}$ Lathifatul Izza, "Melihat Potret Harmonisasi

Hubungan Antar Umat Beragama Di Indonesia", Religi,

Vol IX, No. 1, Januari 2013: 4

${ }^{11}$ Ibid, 5
} 
Indonesia become a peaceful country full of harmony and tolerance so high. On the other hand the religions also voiced, Muslims when she first met say "Assalamualaikum" this reflects that Islam peace loving, so too with Christians is a religion of salvation, Hindu who cling to His Dharma, Buddhism also claims his religion is the way to release the suffering, and Confucianism is also claimed as a religion of love. ${ }^{12}$ See the abundance of the discourse meaning of tolerance needs to be held to its own unity because the renewal getting out is not an influential internal to the Concord community itself not intern into his religion. $^{13}$

The Government in this case does not serve as Arbitrators (the dominant factor that became the benchmark of the existence of religious harmony), ${ }^{14}$ This proves religion is not brought government power. Therefore, the relationship of believers in Indonesia is because the family relationships of the State in Indonesia was created not as a State religion. So many religious pattern found among social communities appear some idea to awake the harmony between different religious, one of which is to conduct a dialogue between religions it is who got special attention from their religions.

\section{Dialogue Between Religions}

Amid the religious diversity that exists in Indonesia with the presence of such a high tolerance, mutual respect between religions is not enough then the need for the existence of a dialogue between religions that provide an understanding of the related understanding of religious teachings one with other religions.

12 Ibid, 6

${ }^{13}$ Kuntojiwo, Dari Kerukunan Ke Kerjasama, Dari Toleransi Ke Kooperasi, (Jakarta: Pustaka Hidayat, 1998), 359

${ }^{14}$ Nurcholis Majid, Fiqih Lintas Agama Membangun Masyarakat Inklusif Pluralis (Jakarta: Yayasan Wakaf Paramadina , 2004), 199
Not that makes everyone else so convinced of his religion and switch the view to switch religions, the dialogue is needed in order to be able to understand other religions teachings of each religion seeds from this attitude of tolerance will the stronger the building intact.

Dialogue between religions is aimed at providing an understanding of the related teaching in the life of each religion, not a religious Academy study let alone discussing all religions and bring forth the new religion and also are you met arguments so that gave birth to the who who wins and who loses, and the loser is obligated to follow his teachings. ${ }^{15}$ Therefore, intercultural dialogue is itself a religious meeting between the heart and mind of the different religions. The dialogue should be applied as one form of religious interaction in keeping unity, togetherness and harmony of different layers that are either religious diera global nor plural.

Leonard Swidle argued there are ten principles that should be held while being religious customs, intercultural dialogue. ${ }^{16}$ First, make the reality of the changes and development in accordance with their respective beliefs. Secondly, the dialogue has to be attended by adherents of different religions and religious adherents intern either different religions. Third, each participant should have a dialog in dialogue and make earnest honesty. Fourth, each participant of the dialogue should be able to describe his beliefs. Fifth, a dialogue without the assumption that firm footing and rush upon conviction that cannot be received. Six, the dialogue undertaken by the party that can absolutely respect and understanding. Seven,

\footnotetext{
15 Burhanuddin Daya, Herman Leonard Beck, Ilmu Perbandingan Agama Di Indonesia Dan Belanda, (Jakarta: Inis, 1992), 208

${ }^{16}$ Leonard Swidler, The Dialogue, Ground Rules For Interreligious Dialogue, (Davao City: Tp, 1990), 95- 98
} 
the dialogue is conducted on the basis of mutual trust. Eight, the dialogue should be followed by people who are critical of that question is can answer all questions and reinforce the confidence of her religion. Nine, dialogue, participants must understand the religious keberagamaan partners either from religion itself or an external call religion. Ten, in customs, the dialogue should not be comparing the teachings of his religion with religious teachings.

Harmonization between different forms of religious people to maintain harmony between different religious, one of which is to establish a dialogue, for mutual trust and respect is not enough should be needed a mature understanding of his religious related own or other religions.

\section{The Three Religions Of The Tenggers}

Tenggerese are the people living in the settlement area of the foothills of Mount Semeru and around the slopes of Mount Bromo, located in the Regency of Probolinggo Regency Pasuruan, Lumajang and Malang. ${ }^{17}$ Tengger Tenggiring Budhi is defined as the mean of sublime nature and Budhi Sublime who is still attached and practiced until now as the ancestral heritage and customary law, according to the society of tengger crater is derived from the word myth in circulation comes from the story of a pair of Roro Anteng and wife husband Joko Seger who first occupied the region of tengger. In the legend, a pair of husband and wife the descendant of 25 children, one of his sons named Kusuma sacrificed being with the Tumbal thrown into the crater of Mount bromo for the sake of the salvation of his brothers. Tengger of Teng (Anteng) and Ger (Seger) which means a society which not many fad and not easily disturbed. ${ }^{18}$ The term was born from the fusion of tengger Roro Anteng and Joko Seger that became the forerunner to the beginning of granting small areas.

The meaning of the term reflected the community's social condition of tenggerese are living in a peaceful, serene setting, mutual mutual, were tolerated despite differing beliefs, understand and obey custom regulations against which are already in force. So don't be surprised if the community is still Small, traditional as well as maintain its cultural order and dutifully against the leaders (Sabda Pandhita Ratu). Obey to preserve traditions such as: traditional ceremony, celebration of holidays, believes the objects invisible, honoring deceased ancestors, and always wearing their distinctive clothing namely gloves that tied at the neck. ${ }^{19}$

Basically this is a small community a community that always communal living simultaneously in realizing a harmonious family is seen from such a high tolerance when doing a ritual customs, building a House simultaneously, farm, attended the celebration fairly is very closely in maintaining religious harmony. Since, the community has a small norm if they don't want to live the tenets will be called as Wong Sing Ora Lumrah or Wong Ora Lumrah. ${ }^{20}$ With such specificity was called by the nickname Wong Tengger (residents perched). ${ }^{21}$

\footnotetext{
${ }^{19}$ Ibid, 29

20 Bambang Subandrijo, Keselamatan Bagi Orang Jawa, (Jakarta: Bpk Gunung Mulia, 2000), 28

${ }^{21}$ Neng Darol Afia, Tradisi dan Kepercayaan Lokal Bagi Beberapa Suku Yang Ada di Indonseia, (Badan Litbang Agama Departemen Ri, 1999),
} 
Most of the communities perched their descendants considered that the original of the Majapahit Kingdom as evidenced by the inscriptions found in the area called the stele of Muncan ${ }^{22}$. This inscription tells about the history of the beginning of the existence of the tenggerese etched with subtle use of old Javanese Script writing on a rock as high as $142.5 \mathrm{~cm}$ with a width of $22 \mathrm{~cm}$ and $102 \mathrm{~cm}$ long while the mount Bromo is a testament to the place their devotion to perform Yajna rituals (dedicated to the gods of the Earth results). In the customs of tenggerese knows no distinction of caste since there is no strong leaders in organizing everything there is only the Dukun (indigenous leader). This is causing a growing spiritual values over time increasingly experiencing life-threatening pemerosotan loss of spiritual and ceremonial life. The year 1945 tenggerese community start digging again trust the spirit began to disappear to apply again in depth. ${ }^{23}$

Wong tengger also have Ordinances in life as listed in Sesanti Panca setya (five clues loyalty) that must be adhered to all walks of life tenggerese because there is no distinction of caste which flourished. ${ }^{24}$ to wit: Satya Wacana (the word must be equal to the deed), Satya culture (kept the custom), Satya Laksana (responsible in tasks run), Satya Semaya (keep a promise), satya Mitra (faithful friend). To achieve happiness life Wong Tengger also steer clear of attitude Mo Lima, Maling (steals), Madon (women's Skeleton), Madat (sucking Opium), Main

\footnotetext{
22 Inscriptions made during muncang Majapahit Empire, at that time a small community named Hila-Hila which means a place that is inhabited by a hermit or holy men to serve God or gods according to the beliefs of Hinduism.

23 Samandhi Widyaprakoso, Masyarakat Tengger: Latar Belakang Daerah Taman Nasional Bromo, 86

${ }^{24}$ Ayu Sutarto, Kamus Budaya Dan Religious (Jember:

Lembaga Penelitian Universitas Jember, 2008) 62

25 Samandhi Widyaprakoso, "Masyarakat Tengger: Latar

Belakang Daerah Taman Nasional Bromo", 9
}

(gambling), Minum (Consuming Liquor), and is obliged to maintain Wa Limo: Wasra (quite sandanf), Wasis ( Enough science), Wisma (has appropriate place), Waras (healthy physical and spiritual), Wareg (sufficient clothing).

After the independence of Indonesia religion embraced tenggerese community still unclear the identity of their existing adhered only carry out the ritual customs such as: Karo-karo Ceremony, Unan-Unan, ceremonial Entas-Entas, Kasodo, and other ritual customs others. New range of years 1973 along with the development of the times, social advancement, technology and norms that was born from the experience of the community itself, ${ }^{25}$ religious coaching related extension began in earnest. According to the statutes, the Parisada community perched including Mahayana Buddhists in accordance with Decree No. 00/PHB Jatim/Kept/III/73, on March 6, 1973, after having reviewed the associated ritual is often done how to worship and trust-a trust that is believed to contain many turns of the teachings contained in the in Hinduism, this is confirmed with the discovery of inscriptions Walandati. ${ }^{26}$ Located in the village of Walandit is situated in the mountains Perched place Hulun Hyang (Abdhi Dewa-Dewi Hindu).

Animism (believe in Supernatural things, spirits, and Life) is also often done community perched like doing Selametan as a form of homage to the ancestors who have important positions in any event, ${ }^{27}$ and also as

\footnotetext{
${ }^{26}$ Walandit inscription is an inscription that tells the story of two events, namely the prohibition of charge Titiloman (dues in performing a ritual ceremony) sacred didesa/Village Walandit around the year 1303 saka or $1381 \mathrm{CE}$, the second, this inscription as well as symbol its designation orders from Bhatara Wekas Ing Suka (posthumous title King Hayaman Wuruk on years of 1327 month Asada).

27 Neng Darol Afia, Tradisi dan Kepercayaan Lokal Bagi Beberapa Suku yang ada di Indonseia, 46
} 
a form of gratitude for natural results that are already given as an offering to the gods so that the God-given no wrath. ${ }^{28}$ When doing a ritual worship community perched also read Japa Mantras (prayers) are up to at the moment still held by Small Quacks, for Small Quacks Mantra is the most sacred treasure as a form of approach with sang Hyang Widhi and also as a Shield so that the exclusion from the evil spirits which harass the tranquillity of life. ${ }^{29}$

From this early have a civilization that does not recognize a difference in the life of society, although religions islam came much after the Hindu and Buddha flourished in a society there is no pre-existing crater can break they bring Division because the community perched very high regard and respect between fellow and gave everyone freedom over seeks to embrace religious teachings and underneath. Seen from a religion that developed in the area of tenggerese not only one religion adopted the local community but many religions that flourished there like Hinduism, Buddhism, and Islam. Beliefs may be different but related, customs and laws there is no difference. A benchmark that is used that is the attitude of the family in accordance with the norms established by the ancestors.

\section{The Hindu Religion}

Hinduism in Indonesia around the 4th century Ad with some evidence of his legacy as a former Kingdom of kutai Yupa Inscription that exists in East Kalimantan, the seven fruits of the yupa found this illustrates that at that time the King of Mulawarman are implement both adoration to the God Shiva. While in the region of tengger's own Hindu religious teachings about 17 th-century under

\footnotetext{
${ }^{28}$ Cart. R.P. Suyono, Mitisisme Tengger, (Yogyakarta: LKiS, 2009), 5

${ }^{29}$ Ayu sutarto, Saya Orang Tengger, Saya Punya Agama: Kisah Orang Tengger Menemukan Agamanya, (Jember: Kompyawisda, 2007), 58
}

Hindu ascetic hermit-by settling in the area around Mount Bromo, Hinduism teaches the meaning of life tenets of good between fellow religions or religions who others who have been described in the Vedic Scriptures like Yajur Vedic Wedha and Atara. Beginning in a small society trust about the homage to ancestral spirits, when entered in the tengger Hindus then adapts to the conditions of the time, a small community so intertwined existence of cultural contact and the teachings of the Hindu religion. Therefore the existence of the Hindu religion is not generally accepted by the community-ripe mature crater but mingled with local culture either of the structure of language, Culture, beliefs, and knowledge development system organizations that are still are traditional. ${ }^{30}$

Existence of the language itself is visible from the language used daily are still using Java language manners, even welcome different pronunciation with Hindu, if Hindu use the word "OM Swastiatsu" tengger Hindu use the word "Hong Ulun Bhasuki Langgeng" meaning (Hopefully Sang Hyang Widhi Wasa always provide Peace, prosperity, and health to all of us). Hinduism in tengger also still thick with customs and culture that develops according to their ancestral heritage preserved mandatory and do taste as a form of homage to the ancestors. The teachings of Hinduism is also not much different from the teachings of the Hindu religion in General in accordance with the described in the Weda.

\section{The Religion of Islam and Budhism}

The teachings of the Islamic religion entered and widespread in the region since the collapse of the crater under the rule of the

\footnotetext{
${ }^{30}$ Muslimin, "Alkuturasi Agama Hindu Di Indonesia, AlAdyan, Vol 7 No. 2, Desember 2012: 67
} 
majapahit Kingdom of demak, Islam in the crater have little difference with Islam as the religion of Islam residing in Tengger still thick with custom and Javanese culture. Already visible from its religious practise there are a number of different things like still involves shamans when people are put on a great day of celebration of Islam, indigenous ceremonies such as karo-karo, unan-unan, kasada and others still followed by the Islamic society, it also customary ceremonies is still used as the media claims by islam. Reverence for ancestor spirits are still retained by the small Islamic community. Islam does not have to be placed in the context of the Shariah, but also about the substance of Islam itself, in the teachings of Sufism that rests on the Quran, the Hadith. The Prophet Muhammad's life practice setra. In harfiyah Sufism believes that the Messenger in teaching Islam always respecting the ancestral cultural legacy without having to remove it rather adapts to existing conditions. ${ }^{31}$ Issues fixed in accordance with the Shari'a Islamic teachings such as carry out prayers, fasting, and the teachings of Islam. Islam in the crater include Islamic syncretic religious practices in teaching because there is a fusion of several familiar customs, culture and beliefs of other religions.

In addition to the religion of Islam and Hinduism in the region there is also the tenggerese teachings of Buddhism, however when the new order teachings of Buddhism in tengger examined in 1973 by the Ministry of religious affairs through the Hindu-Buddhist Bimas Director General. It turns out that once researched communities perched entered into the religion of Mahayana Buddhism, the

31 Aki Maksum, "Politik Identitas Masyarakat Tengger Dalam Mempertahankan Sistem Kebudayaan Dalam Hegemoni Islam Dan Kekuasaan", El- Haraq, Vol 17, N0. 1 , Tahun 2015: 33

32 Sutarto, 1998 decision is still not final because the leaders of Buddhism tengger remained decided they were Buddhists (Crater). And the dikeluarkanlah Decree No. 00/PHBJatim/Kept/III/73 tertanggalkan March 6, 1973.

\section{The interaction of the relationships between religions in the Tenggerese}

Tenggerese community that is still fairly agrarian yet work directly with konsumeristik, and materialist culture. They will persist amid the globalization age hanging from the Dukun (Indigenous Leader) who holds the most important share as heirs of the tradition and culture of sustainability in the Tengger. ${ }^{32}$ Although they get a good influence in terms of religious, economic, social, and culture on a small quacks still plays an active role as the heir to the throne of Majapahit and Walandit. Despite the belief that embraced each citizen is not the same but when doing a ritual customs retains the tradition that developed in the region of Tengger. The ceremony is performed Hindu rituals like smell still: Kropak, Prapen (place of fire and Incense), Genta, and Sampet (the yellow scarves usually used by Hindu priest at the time of Majapahit). ${ }^{33}$ The spirit of pluralism are embodied by loving the culture and religion that makes them prone to the appearance of a conflict as well as social inequality or ethnic prolific religious diversity.

Technological developments that increasingly rapid exciting tengger residents drove to try new things, but not affected Oleh trend and lifestyle that many posts in the media most of them positioned itself be Wong

\footnotetext{
33 Wimmy Halim, "Identitas Wong Tengger Masyarakat Desa Ngandas: Refleksi Kebangsaan Atas Degradasi Identitas Dan Persatuan Nasional", Vol 2, No 2, Tahun 2006
} 
mountain (mountain citizens) than be Wong Ngare (lowland residents living in urban areas). According to their urban communities very different from mountain communities like her own life and seldom gather together unless there is activity which is important.

\section{Pillars of cultural Tolerance and Tenggerese}

The pillars have become the hallmark of a society in tengger interact, making this community is rukunnya values of tolerance as a foothold to live bersosial as well as religion. The meaning of tolerance itself an effort in creating a harmonious society by way of respect between fellow, mutual trust, mutual cooperation in order to achieve one of the community in the absence of social inequality. ${ }^{34}$ Attitudes inherited the ancestral pillars embodying the order conditions of society a peaceful perched even hardly finds social or religious conflict it reflects the existence of difference is not a barrier to strengthen the brotherhood. ${ }^{35}$ The elite society teaches that Jesus taught compassion and love, Prophet Muhammad exemplifies the gratitude for the favors of Allah almighty, Buddhism teaches man to take the Middle Road, and the gods taught humans to fight falsehood and uphold the truth. ${ }^{36}$ According to the residents of a small "better a lot of brothers on many treasures". ${ }^{37}$ Saying this is what makes Concord residents. Fostering these values with proven good views from the model of their life that is full of warmth and harmony.

\footnotetext{
${ }^{34}$ Muhammad yasir, makna toleransi dalam al- qur'an, vol 22,no 2, tahun 2014

${ }^{35}$ Fatmawati 2013

${ }^{36}$ Nyoman S. Pendit, Nyepi: Kebangkitan, toleransi dan Kerukunan, (Jakarta: Gramedia Utama, 2001), 59

${ }^{37}$ Wawancara, dengan dukun suku tengger

38 Harry Waluyo, Sistem Pemerintahan Tradisional di Tengger Jawa Timur. (Jakarta: Proyek Pengkajian dan Pembinaan
}

A small community also knows of the Welas Asih Pitu ${ }^{38}$ (seven-love affection) including: Welas Asih Marang Bapa Kuasa (God), Welas Asih Marang Bapa Biyung (parents), Welas Asih Marang Ibu Pertiwi (Motherland), Welas Asih Marang Jiwa (sense of soul), Welas Asih Marang Sepadane Urip (Fellow Humans), Welas Asih Marang Sato Kewan (Animals), Welas Asih Marang Tandur Tetuwuh (Vegetation). In this small community adage emphasized to do good to your fellow man in spite of different beliefs not only of human beings, nature, plants, and animals also must also remain guarded this cause with a small community cancord.

The realization of the values of diversity not only Prime this historical evidence has recorded values of harmony has been there always used to be in this tribe. Especially when many Travelers (newcomers) that berbondong-bondong present to this area, concerns and convenience have appeared, so as to unify this society the shamans of the initiative made the Ceremony as a unifying customs the Community element of the tengger layer both Hindu, Buddhism, and Islam. ${ }^{39}$ Like the ceremony of Unan-Unan i.e. the largest ceremony for the community of tengger which is done in sewindu once sewindu, the calculation is different from the calculation of the saka calendar tengger, according to sewindu it's not eight years but five years appropriate with the calculation of the sun rising every day even thirty days. A small calendar mentioning that no months of twenty-nine days or thirty-one days. This is almost the same as the calendar system is that

Nilai-Nilai budaya, Direktorat Sejarah dan Nilai Tradisional, Direktorat JenderalKebudayaan, Departemen Pendidikan dan Kebudayaan, 1997), 86

39 Sudiro, Legenda dan Religi Sebagai Media integritas bangsa, Vo 8, No 1, Sebtember 2001, halaman 19-30 
there are only 5 days: Pon, Wage, Keliwon, Pahing, Legi, so one week there have only been five days and sewindu only for a period of five years. ${ }^{40}$ Mbah sindek (Elders of the village Shaman Agrosari) say unan-unan comes from the word Nyaur which means Hunan Banggi (a promise to pay), described in Makekat Jungring Saloko as follows:

"Leluhur kawula paringi pitedah wewarah kados ingkang kasebat wonten mekakat junggring saloka. Bilih Wong agung kiko dakso, dawuhaken Prabu Anom Sangge menyan kebak pelambung. Ki Ageng Ardi Anas Nambi Meru. Nyampuhaken putra wayah giri kusmo pikantuk nyi buring mbok wulanjar ingkang wonten sanggar ratu anom pemancil, ingkang nemurunaken yugo putu wonten saidenge poten tetenggere tanah pulo jawi”.

There are several requirements that must be provided in a ceremony such as: Gedang Ayu, Suruh Ayu, Jambe Ayu, and the most important of the White Buffalo. Ritual ceremony began with Rawa Tangkang (the reading of sacred mantras with the intention of asking permission To Bahu Rekso (the term's leader at the time of the Kingdom) and also the spirit of the ancestors of the membabat of the base region of tengger. Second, Mapek (Ceremonial Opening attended by Councilor and the ranks of the Government). Third, Unan-Unan (ritual slaughtering is done by White Buffalo are devoted to God as a gratitude for the favors of nature that have been given so that the living can would be sure and also as a form of petition in order for exclusion of things that effect is negative). The most interesting thing here is when the ceremony of the slaughter of Buffalo skin and bones left intact only taken

\footnotetext{
40 Wawancara dengan bapak budiono (Dukun Suku
} Tengger), di desa Agrosari pada: 25 November 2018 part meat punctured and decorated over the past tengkurap Buffalo body decorated with produce such as gedhang ayu, vegetable, and fruits more then paraded from the scene of the slaughter toward Penden Desa in Pure (where the first establishment of buildings in an area). The evening held a ceremony with an already prepared to enjoy the rest of the community attend mandatory either tengger Hindus, Buddhists and Muslims. In this sense of family banquet feels real they feel both have stories of history and public order that are parallel. Because all blend into one without restrictions in the frame of family although it is this trust and understand different forms of a togetherness in the frame of keberagam religious but still family.

In addition to the ceremonial unanunan there is also a tradition of Karo-Karo ceremony that is the tradition of the great ceremonies conducted by the public good of Islam, a small Hindu, or Buddhist. The celebration ceremony was not much different from the feast of Eid al-Fitr and Eid al-Adha, where Karo-karo was performed for two weeks in the second month of the lunar crater or the crater will call it Moon Karo. Just in today society tengger bermaaf-maafan each other and also visited every house in the local community, the most memorable in the ceremony there is slaughtering all cattle results both from the Chickens, goats, pigs, cows and Buffaloes for enjoyed his flesh. This celebration for the community perched very highly because of hard work as a reward for a year of good farming, farming or berternak. All walks of life good old-young, large and small, Hindu, Islam, Buddha blend into one joyous celebration in karo. The celebration of this increasingly impressed karo complete and lively if yields abundant. ${ }^{41}$

${ }^{41}$ Sutarto, Komunitas Lokal Dalam Persefektif Perubahan Sosial Budaya: Suku Tengger, (Jember: Universitas Jember, 1997), 211- 212 
And the last Rites or Kasodoan i.e. Kasada ceremony conducted on 14, 15, 16 instead of kasodo to coincide with the full moon was being radiated and looks at Lazuardi feast now known as Yadnya Kasada. Yajna Kasodo rather like the well of feast of sacrifice and also produce animal sacrifice as a form of preservation of progenitors mandate tenggerese Raden Kusuma aka Patni Kusuma aka Kusuma Deity who was the youngest son of Rara Anteng and Jaka Seger. Kosodoan this as a form of communication between the tenggerese with God and the ancestor spirits guarding the area of tengger, this interaction is done as the heir to a tradition in the active crater. Not only does this ritual followed Hindu religion but also Islam, Buddhism and Christianity through several stages as ${ }^{42}$ : first, the taking of the eyes (holy water holy water is taken from the mountain Widodaren as complements the first before doing Yadnya Kasada, which made Ngelukat people (the purification of the Soul Society Tengger). ${ }^{43}$ Second, the opening of the Yajna (opened by the Parisada Hindu and Juge whole the shaman tenggerese either from Lumajang, Probolinggo and Pasuruan, Malang, held at Ponten (Sand Sea mount Bromo) ${ }^{44}$ Third, this ritual (Kasada Ceremony starts at 02.00 Pm$07.00 \mathrm{pm}$ EST with a variety of events such as the preparation of the event, Reciting chants, Ngelukat people (purifying People, places of worship and place of the gods), the reading of the Vedic Scriptures, The history of the Kasada, Muspa (persembayangan), the prayer after Worship, Election Candidates, the Shaman Lelebuhan (Enter) offerings into the crater of Mount Bromo,) in the core kasodo is widely followed by Hindus because if analyzed in terms of ritual many contain elements of Hinduism, so when the ritual of progresses people other than Hindus is only present to witness. Recently the last end of the event, namely Pepujaan (Selametan) this event do Poten each with enjoying the natural results led by the local village elders and Shamans). ${ }^{45}$

This is a manifestation of religious harmony in the formation of the Tenggerese, where the Customs and culture of the ancestral heritage which makes the third religious in the Tengger into one unit in the frame to build a religious tenets and peace. Social identity is strengthened by developing the values of tolerance that automatically binds the existing cultures in Indonesia into a unity. When the tenggerese could unite, and only a small part of the State in Indonesia who are capable of practising sila 3rd in pancasila Indonesia Unity i.e.Where unity is progress, and unity not achieved without any process. With the Union, though separated on a Regional basis, not an easy integral values such as masayarakat evolved from this crater to uphold the existence of religious harmony. Attitudes like this should be emulated all walks of life to maintain the unity of Indonesia Indonesia making customs and culture as a unifying religious.

\section{CONCLUSION}

A small community known as strong Community Customs and culture. In the middle of the process of civilization that is so long it is very evident that the community does not falter for the tengger always hold fast to the ancestral heritage handed down the hereditary, based on exposure above prove
42 Juli Astutik, Makna Ritual Upaca Kasada Dalam Persefektif Antropogi, Dalam Agama Tradisional, (Yogyakarta: Lkis, 2003), 128- 131

43 Mohammad Anas, "Telaah Metafisik Upacara Kasada, Mitos Dan Kearifan Hidup Dalam Masyarakat Tengger”,
Kalam : Jurnal Studi Agama Dan Pemikiran Islam, Vol 7, No 1, Juni 2013: 26

${ }^{43}$ Ibid, 27

44 Ibid, 32

45 Ibid, 32 
though religions good Religion Hindu, Buddhist, and Muslim occupied the crater did not shake the slightest sense of family that there are precisely religious diversity which further strengthened religious based interfaith harmony as well by holding fast to the mores and cultures developed for maintaining harmony. Realization of the harmony itself were carried out in the presence of customs and culture like Karo, ceremony Ceremony Unan-Unan, Kasada Ceremony, ceremony of the birth and death rituals. There is no caste differences that bind because on the tenggerese caste distinction does not teach that there is only a small Wong (Tenggerese Community).

Concord-based model of culture contained in the tenggerese lies in Lumajang, Malang, Probolinggo Regency, and Regency Pasuruan, whose inhabitants converted to Hinduism, Buddhism, Islam. This happens because the local wisdom preserved well beyond the religious bonds, for their respect for ancestors and adhere to the most important Shaman in order to obtain a harmonious and peaceful life. The condition of this harmony embodied in the social practices of the tenggerese community, relations between the communities is also entwined with either because of the attitude of tolerance in the society with good which is based on the values of culture Tengger.

\section{REFERENCE}

Ali Hisyam. Mohammad. 2015. Harmonisasi Lintas Agama Masyarakat Tengger. Vol 10. N0 01. September

Ali. Mukti. 1997. Ilmu Perbandingan Agama, Dialog, Dakwah Dan Misi. Jakarta: Inis.

Ali. Mursid. 1999. Plularitas Sosial Dan Hubungan Antar Agama Bingkai Kulturall Dan Theologi, Kerukunan Hidup Umat Beragama. Jakarta: Badan
Peneliti Pengembangan Agama Depag RI

Anas. Mohammad. 2013. "Telaah Metafisik Upacara Kasada, Mitos Dan Kearifan Hidup Dalam Masyarakat Tengger". Kalam : Jurnal Studi Agama Dan Pemikiran Islam. Vol 7. No 1. Juni

Aqil Al- Munawar. Said. 2005. Fiqh Hubungan Antar Agama. Jakarta: Ciputat Press

Astutik. Juli. 2003. Makna Ritual Upaca Kasada Dalam Persefektif Antropogi, Dalam Agama Tradisional. Yogyakarta: Lkis

Dangun. M. 1997. Kamus Besar Ilmu Pengetahuan. Jakarta: Lembaga Pengkajian Kebudayaan Nusantara

Darol Afia. Neng. 1999. Tradisi Dan Kepercayaan Lokal Bagi Beberapa Suku Yang Ada Di Indonseia.. Badan Litbang Agama Departemen RI

Daya. Burhanuddin, Leonard Beck. Herman. 1992. Ilmu Perbandingan Agama Di Indonesia Dan Belanda. Jakarta: Inis

Djatiwijono.H.R. 1983. Dinamika Kerukunan Hidup Beragama Di Daerah. Jakarta: Maret

Halim.Wimmy. 2006. "Identitas Wong Tengger Masyarakat Desa Ngandas: Refleksi Kebangsaan Atas Degradasi Identitas Dan Persatuan Nasional”. Vol 2. No 2.

Izza. Lathifatul. 2013 "Melihat Potret Harmonisasi Hubungan Antar Umat Beragama Di Indonesia”. Religi. Vol IX. No. 1. Januari

Kuntojiwo. 1998. Dari Kerukunan Ke Kerjasama, Dari Toleransi Ke Kooperasi. Jakarta: Pustaka Hidaya Majid. Nurcholis. 2004. Fiqih Lintas Agama Membangun Masyarakat Inklusif Pluralis. Jakarta: Yayasan Wakaf Paramadina 
Masum. Ali. 2015. "Politik Identitas Masyarakat Tengger Dalam Mempertahankan Sistem Kebudayaan Dalam Hegemoni Islam Dan Kekuasaan". El-Haraq. Vol 17. N0. 1 Mundar Soelaeman. M. 1987. Ilmu Sosial Dasar Teori Dan Konsep Ilmu Sosial. Bandung: ERSCO.

Muslimin. 2012. "Alkuturasi Agama Hindu Di Indonesia, Al-Adyan. Vol 7 No. 2. Desember

S. Pendit. Nyoman. 2001. Nyepi: Kebangkitan, Toleransi Dan Kerukunan. Jakarta: Gramedia Utama

Subandrijo. Bambang. 2000. Keselamatan Bagi Orang Jawa. Jakarta: Bpk Gunung Mulia

Sudiro. 2018. Legenda Dan Religi Sebagai

Media Integritas Bangsa. Vo 8. No 1. Sebtember 2001

Sutarto. 1997. Komunitas Lokal Dalam Persefektif Perubahan Sosial Budaya: Suku Tengger. Jember: Universitas Jember

Sutarto. Ayu. 2007. Saya Orang Tengger, Saya Punya Agama: Kisah Orang Tengger Menemukan Agamanya. Jember: Kompyawisda

Sutarto. Ayu. 2008. Kamus Budaya Dan Religious. Jember: Lembaga Penelitian Universitas Jember

Suyono. Cart. R.P. 2009. Mitisisme Tengger. Yogyakarta: Lkis

Swidler. Leonard. 1990. The Dialogue, Ground Rules For Interreligious Dialogue. Davao City: Tp

Tri Haryonto. Joko. 2004. Kearifan Lokal Pendukung Kerukunan Beragama Pada Komunitas Tengger Malang Jatim. Vol 21. No. 2

W. Hefner. Robert. 1985. Hindu Javanes And Tradition Islam. Princeton: Princeton University Perss
Waluyo. Harry. 1997. Sistem Pemerintahan Tradisional Di Tengger Jawa Timur. Jakarta: Proyek Pengkajian Dan Pembinaan Nilai-Nilai Budaya, Direktorat Sejarah Dan Nilai Tradisional, Direktorat Jenderalkebudayaan, Departemen Pendidikan Dan Kebudayaan.

Widyaprakoso. Samandhi. 1994. Masyarakat Tengger: Latar Belakang Daerah Taman Nasional Bromo. Jakarta: Kanisius

Yasi. Muhammad. 2014. Makna Toleransi Dalam Al-Qur'an. Vol 22. No 2

\section{Other Sources}

Al-Quran, Surat Al Hujurat Ayat 13

Wawancara Dengan Bapak Budiono (Dukun Suku Tengger), Di Desa Agrosari Pada: 25 November 2018 